paths of 1,390 meteors were recorded. The great majority of these belonged to the sporadic class-a result in agreement with that obtained by the Harvard Expedition to Arizona in 1931. The month of December was most prolific, yielding a total of 472 meteors, and on some nights the hourly rate was about forty. An analysis of the magnitudes of the meteors observed is interesting and the table given below will show the relative paucity of very bright meteors. Eight were so faint that no definite magnitude could be assigned to them, and 117 had magnitudes between $4 \cdot 5$ and $5 \cdot 5$. The others were classified as follows :

$\begin{array}{llllclcc}\text { No. } & \text { Mag. } & \text { No. } & \text { Mag. } & \text { No. } & \text { Mag. } & \text { No. } & \text { Mag. } \\ 207 & 4 & 208 & 2 \cdot 5 & 5 & -2 \cdot 5 & 6 & -4 \\ 182 & 3 \cdot 5 & 190 & 2 & 6 & -3 & 3 & -5 \\ 188 & 3 & 268 & 1 \cdot 5 \text { to }-2 & 1 & -3 \cdot 5 & 1 & -7\end{array}$

Of the bright meteors, 17 were observed after midnight and 5 before midnight, the meteor of mag. -7 being included in the former class. It was observed on March 22d. 15h. 42m. U.T. and gave off a number of sparks during its flight. It is suggested that some of the debris may have fallen to the earth. The usual shower meteors were badly represented, only thirty-six being recorded. Some very bright meteors had low apparent speeds and one in particular is worth mentioning. On Oct. 19 a reddish meteor, mag. 0, took half-aminute to cover its track of $25^{\circ}$. Another interesting point is that, while meteors of 2.5 to 3 mag. occasionally gave persisting streaks, brighter meteors failed to do so in many cases even when they were appearing to move swiftly. It is suggested that streaks are produced only in certain definite regions of the atmosphere if the meteor has a high geocentric velocity.

\section{Seismological Data from Australia}

VALUABLE data concerning earthquakes during the period October-December 1940 have just been received from the Riverview College Observatory, New South Wales (director, D. J. K. O'Connell, S.J.). During this period sixty-three earthquakes were registered and interpreted, eleven giving a maximum amplitude greater than $2 \mathrm{~mm}$. The greatest am. plitudes were on November 27, 1940, when an amplitude of $7.3 \mathrm{~mm}$. was recorded by the northsouth component seismograph and $9.0 \mathrm{~mm}$. by the east-west component. This earthquake was felt at Neinduk, at North Baining with intensity 6 on the Rossi-Forel scale, at Kavieng R.F. 5 and at Rabaul R.F. 4-5. The earthquake of November 22, 1940, which only gave a maximum amplitude of $0.5 \mathrm{~mm}$. at Riverview was felt at Rabaul, New Britain R.F. 4, Neinduk R.F. 3, Pondo R.F. 5 and Kuridui R.F. 4. Microseisms prevented the interpretation of some seismograms on which the earthquakes only recorded with small amplitude.

\section{Antonio Pacinotti (I84I-I9I2)}

ON June 17 occurs the centenary of the birth of the Italian physicist Antonio Pacinotti, who contributed to the early development of the dynamo. Born at
Pisa, where his father, Luigi Pacinotti, held the chair of physics, he worked in the physical laboratory of the University, and it was while a youth of eighteen serving in the Garibaldean wars that he pondered over electromagnetic problems. At the age of nineteen he devised an electric generator with a ring armature which he described in Il Nuovo Ciminto of May 3, 1865. Though, unlike his contemporaries Jedlik and Hjorth, he did not conceive the possibility of selfexcitation, his machine had outstanding results. When twenty-one Pacinotti became assistant astronomer at Florence and afterwards held professorships of physics at Bologna (1864), Cagliari (1873) and Pisa (1882), to which place he returned on his father's death. His achievements were recognized in many ways, and in 1902 the Institution of Electrical Engineers elected him an honorary member. $\mathrm{He}$ died at Pisa on March 25, 1912. The seventy-fifth anniversary of his invention was commemorated at Pisa in 1934. A life of Pacinotti has been written by Prof. Polvani, of the University of Milan.

\section{Raymond Vieussens}

THIs year marks the tercentenary of the birth of the celebrated French anatomist Raymond Vieussens; the exact date of his birth is not ascertainable. $\mathrm{He}$ was born at a village of the same name in Rouergue, the son of a lieutenant-colonel. $\mathrm{He}$ received his medical education at Montpellier, and at the age of thirty became physician to the Hospital of St. Eloys. During the first ten years of his service there he performed five hundred autopsies not only to find out the cause of death but also to discover the normal structure of the brain and spinal cord and follow the nerves from these organs to their insertions. In 1684 he published the results of his investigations in a work entitled "Neurographia Universalis", which contained the most complete description of the brain and spinal cord hitherto given and won him a great reputation throughout Europe. He was elected fellow of the Royal Society in 1688 and a member of the Royal Academy of Sciences in Paris.

In 1685, shortly after being summoned to Paris by Louis XIV to attend the Marquis de Wardes, Vieussens was appointed physician to Madame de Montpensier, cousin to the king, and held that office until her death in 1693 when he returned to Montpellier. In 1705 he published his "Novum vasorum corporis humani systema" which contained a record of several interesting autopsies. In 1715 , the year of his death, he brought out a "Traité nouveau de la structure et des causes du mouvement naturel du cœur", which is remarkable for a description of mitral stenosis and of the pulse of aortic incompetence. In addition to his works on the nervous and cardiovascular systems he was the author of an important work on the structure of the ear (1714). He also discovered the fermentative effect of the saliva and the presence of an acid in the blood. Vieussens's name was formerly at.tached to a number of anatomical structures, but was omitted in the Basle nomenclature introduced in 1895, so that it is no longer familiar to the rising medical generation. 